\title{
Conservation Crossroads and the Role of Hierarchy in the Decision-Making Process
}

\author{
Adrián Monjeau
}

Instituto de Análisis de Recursos Naturales, Universidad Atlántida Argentina \& CONICET, Mar del Plata,Argentina

\begin{abstract}
This essay examines several crossroads, paradoxes and controversies in conservation politics in Latin America: populated and non-populated protected areas, local versus global forces, and the role of the national government in making long-term, ecologically correct decisions versus short-term politically correct local decisions. Ecologically sound projects at a global scale such as the maintenance of the ecosystems working order, exceed the lifetime of the present generation. In addition to this, as decisions in a particular area may have ecological consequences that go beyond the sphere of that area, the responsibility cannot be delegated to the local management level. Local consensus is essential to implement conservation goals on the ground, but it should never be opposed to global priorities, especially because this antagonism puts the ecosystem working order at risk. In this ranking, the hierarchical organization of the decision making process, from global to local, is crucial, so that the State retains its organizational role while working along with the local forces in their effort to implement conservation.
\end{abstract}

Key words: Protected Areas, People \& Parks, Politics, Biodiversity, Global versus Local.

\section{Introduction}

The huge demographic growth and burst of western techno-capitalism has given place to a world map in which the human footprint has reached and domesticated almost every single patch of fertile land (see Sanderson et al. 2002). This devastating force has homogenized and simplified landscapes across the globe and made them accessible to the language of multiplication of capital. This landscape transformation is contributing to ever faster declines in species and the system they depend on (Agrawal \& Redford 2007). Most of the world's diversity, be it in biology, wildlife, ethno-linguistic groups and other minorities that still survive landscape transformation, is fenced into the last corners of the planet, where the global market routes have not reached yet. For this reason, a great part of the areas with the highest biological diversity also enclose the largest linguistic diversity (Toledo 2001, 2005).

In other words, several non-protected wilderness areas in developing countries still survive thanks to their inaccessibility (Monjeau 2007). As a result, whether those wildernesses will survive or not depends on road construction. On behalf of the progress, soon remoteness will be a thing of the uncivilized past. Resources of all

*Send correspondence to: Adrián Monjeau Instituto de Análisis de Recursos Naturales, Universidad Atlántida Argentina y CONICET, Arenales 2740 (7600) Mar del Plata, Argentina E-mail: amonjeau@parkswatch.org kinds will be exploited to exhaustion unless restrictions are vigorously imposed (Terborgh 1999). Natural landscapes in arable land will disappear. There are many examples of what has happened in remote areas where the global market has been able to extend its reach. It is in these places that non-protected ecosystems are now strongly altered, while strictly protected areas have demonstrated their capacity to resist landscape transformation (Bruner et al. 2001). If it were not for the pioneering efforts of a few people capable of understanding the future, today we would be unable to enjoy the national parks that harbor the last bastions of wilderness on Earth (Soulé \& Terborgh 1999).

\section{Are Protected Areas Enough to Stop Extinction?}

Even though protected areas are acknowledged as the most efficient and necessary tools to safeguard the last remnants of wildlife (Bruner et al. 2001, Brooks et al. 2006; Kramer et al. 1997), they are not enough to stop global losses in biodiversity and wild places. Conservation scientists have realized that protected areas, if isolated, cannot achieve their objective of sustaining natural functioning and diversity (Newmark 1987; Belovsky 1987; Soulé \& Terborgh 1999). In order to achieve this objective, it is necessary to manage large interconnected extensions dedicated to conservation, managing ecosystems as integers (Soulé \& Terborgh 1999; Toledo 2005; Interagency Ecosystem Management Task Force 
1995). Consequently, effective biodiversity conservation must include conservation outside the boundaries of protected areas (Allison et al. 1998; Soulé \& Terborgh 1999). These goals are coupled to problems that exceed the reach of biology, since the management of entire ecosystems implies the accommodation of the best possible mosaic between stakeholders of diverse interests that overlap in a very complex way the objectives of conservation (Brandon 1998, 2002; Brandon \& Wells 1992; Brandon et al. 1998; Ritcher \& Redford 1999; Salafsky \& Wollenberg 2000; Wondolleck \& Yaffee 2000).

Consensus is the most desirable attitude to achieve these conservation objectives at an ecosystem scale. This does not mean, however, that a consensus will coincide exactly with the ecologically correct decisions in every single grid of the mosaic, since the consensus finds its limits where the diffuse collective interests of stakeholders imply restrictions on individual ones (Peterson et al. 2005). This is a commons problem. Paraphrasing Garrett Hardin (1972), we could argue that the "I-here-now" has a vast preference over the weaker "All-there-after". This tragedy of the commons has ultimately structured the present world map and its tendencies. The current biodiversity crisis is caused in part by the accumulation in time and space of zillions of little local decisions that disregard further global consequences.

Taking this statement into account, we believe that the State, that represents us all everywhere in the long term, should be the integrating tool for the above-mentioned mosaic, considering that its main objective is the regulation of individuals for coexistence to be possible.

It has been demonstrated that internal and external pressures will eventually transform a natural area which is under no conservation management of any sort. The main issue would be how much of the wild areas is actually safe from the pressures of transformation. In a recent study (Monjeau 2007) it was calculated that the percentage of protected areas under strict conservation management without pressure from their surroundings is in the order of $8 \%$ (a total of 1511 protected areas were studied) in South America. This is obviously in short supply to carry out functions such as preservation of biological diversity, endemisms and ecosystem processes crucial to human and natural economy: soil fertility, global temperature regulation and water provision. If the remaining $92 \%$ depend - to any degree - on achieving a consensus between conservationist agendas and the surrounding social entities and villagers, one core question of this essay would be to what extent the State can uphold a set of correct ecological decisions vis-à-vis such a consensus.

\section{Politically Correct or Ecologically Wise?}

The problem is not simple. There seems to be an inverse relation between what is politically correct and what is ecologically acceptable. In today's world, nature conservation movements find themselves at a crossroads, where two extreme myths or beliefs are dialectically opposed (Monjeau \& Solari 2008; Terborgh 1999; Terborgh et al. 2002; Schwartzman et al. 2000; Wilshushen et al. 2002): 1 ) it is impossible to establish effective conservation if people are involved; 2) it is impossible to establish effective conservation if people are not involved. Both assumptions coexist under pressure inside the core of the conservation paradigm because they are only partly correct. Arguments in favor of myth 1 are built upon the belief that human presence invariably impacts nature negatively. Arguments in favor of myth 2 suggest that a harmonious and sustainable relationship is the only way that conservation goals can be achieved. It is not hard to guess that the coexistence of these two approaches generates a great amount of confusion in conservation policies. This gives way to the bewildering fact that the engine driving the history of conservation has become dialectical (sensu Hegel 1966) between abuse and inexperience.

\section{The Abuse Factor}

The abuse factor is clearly exemplified by the first blunders committed during the periods of land occupation and subsequent territorial designation (Redford \& Fearn 2007). Protected areas - preceded by a history of usurpation and even genocide at a regional scale - find themselves in conflict with the rights of the original inhabitants who were forcedly displaced from them. At this end of the spectrum, the unviability put forward by myth 2 is understandable, since in the memories of the usurped there is a "karma" against conservation as a symbol of imposition by a foreign enemy who expelled them from their native lands. To make the issue even more complex, due to the fact that just a few elite or rich people have been displaced as the result of the creation of protected areas, "the usurped linked conservation with a concern of the wealthy and the powerful" (Brosius 2007). Given that perception, displaced people or people with restricted access to local resources may have strong incentives to destroy wildlife and resources in protected areas (Brandon 2002; Delrio 2005; Brosius 2007). As Brosius (2007, p. 106) puts it:
[...] In several forums, local community advocates have put forward propositions for organizing reconciliation commissions which inquire into past injustices promulgated in the name of conservation, and the idea of restitution is receiving increasing attention.

The pressures to return to the use of the natural resources in their native forests, valleys and prairies (also understandable) swell up in the public consciousness to a point where myth 2 becomes valid. Recently, WWF (Worldwide Fund for Nature 2006) published an assessment of the case in which humans and wildlife species can coexist and prosper. In the same avenue of pressures against myth 1, conservation has become the target of indigenous movement. In their discourses "they have come to equate conservation with the extinguishing of rights, the latest in a long line of attempts to dispossess them", as Brosius (2007) puts it. In most of 
the wilderness settings where many important protected areas and peripheral settlements are located, conservation success is likely dependent on local acceptance or resistance (Redford \& Fearn 2007). This is another argument to validate myth 2 . However, when the State grants the lands, conservation goals are not part of their subsistence practices (again, understandable as well as justifiable). The empirical evidence shows that a free-for-all human use is generally not compatible with biodiversity conservation. Bottom-up decision making processes will not improve the security of parks if they rely a hundred percent on voluntary compliance (Terborgh 1999). There are many examples of the failure of voluntary compliance to produce the desired results. For instance, Agrawal \& Redford (2006) survey of 37 projects which attempted joint achievement of biodiversity conservation and poverty alleviation found little evidence in favor of synergies between human use and conservation. These facts tend to re-validate myth 1 , and so the dialectic continues.

\section{The Inexperience Factor}

The inexperience factor consists in presuming that the debts of abuse can be paid merely by putting the conservation goals of protected areas in the hands of their original inhabitants or local communities (the "positive-historical" conservation action in Agrawal \& Redford 2007). This is a short-term demagogic approach, politically naïve, that compromises the public's right to live in a healthy environment, endangers the planet's inhabitability and - worst of all - does not repay the debt of a shameful injustice of continental dimensions! To cover up errors with more errors does not seem to be the wisest road to a fair, ethnically integrated society that is in concord with its ecosystem; it is more like a road to the political positioning of a few opportunistic individuals who take advantage of the dynamics of consensus. In this way they favor the process of deconstruction of the State towards territorial tribalization.

The confluence of critiques that blunt the ethical focus of biodiversity conservation highlights the distress that conservation goals impose to human populations. This ethical side of the criticism have gained a great deal of attention in international forums such as the World Park Congress (see Terborgh 2004, 2005 versus Andrade 2005), World Conservation Congress and Convention on Biological Diversity Conference of the Parties, and in international conservation organizations like WWF, CI, TNC, WCS, and IUCN. This is one of the most critical problems confronting conservation worldwide.

However, whether the restrictions imposed to local populations are justified or not on behalf of global, longterm conservation goals is perhaps alongside this point: the vociferous human rights criticism regarding a lack of synergy between conservation and social goals has undeniable negative impact on conservation funds. Because available funds for conservation have declined in comparison to the increasing emphasis on social equity and poverty alleviation, conservation organizations are shifting the message persuading donors that conservation can be accomplished together with poverty alleviation (Wells \& McShane 2004) and that biodiversity conservation is important in ecosystem services for human well being in the long run (Burton et al. 1992). Under these new banners of "conservation and human needs", conservation groups have had impressive rates of financial growth (Terborgh 1999).

Likewise, a confluence of the major international donors (under the pressure to adopt greener policies) and conservation organizations (wanted to be seen by these donors as "social sensitive") converged in the form of integrated conservation and development projects, called ICDPs. The contribution to conservation claimed by the ICDPs is to reduce external threats to parks by promoting sustainable development outside the protected areas. However, under the "socio-green" shield, the ICDPs contain a mixture of inexperience working together. On one hand, big international donors, like the USAID, have little experience in conservation. On the other hand, conservation organizations are inexperienced in managing international development projects.

Conservation projects have been spending millions of dollars in economic assistance to local villagers and promoted development with little benefits for conservation. On the contrary, due to the synergy between two processes, the inexperience factor under discussion may be the cause of an "eutrophication effect" negative to conservation: 1) Improvements in the livelihood of villagers inside or near parks stimulate migration from other places, population density increases, and consequently, pressure on the park's resources increases. 2) Local villagers might voluntarily respect park boundaries and other restrictions if they could raise their standards of living through means other than exploitation of the park's resources. Nevertheless, alternative economic activities supported by external sources of money may stop when the source of money is discontinued.

Then, the hope of a better life on behalf of conservation disappears in no more than the blink of an eye. Millions of dollars later, the situation is worse than it used to be: a much bigger population which is unwilling to believe in new promises and claiming for the use of the park's resources as they did before.

As far as we can see on the ground, there is a false link between ICDPs and conservation. If the goal is conservation of biodiversity, investment in local people is the wrong target.

\section{Who Will Advocate for the Defense of Nature?}

This uncertainty between the right way and the convenient way is another tectonic movement in the philosophical roots of conservationism. Unfortunately, if conservation organizations are reluctant to go where criticism wishes them to go, the financial forces will push them into putting more emphasis on the social issues than on biodiversity 
conservation priorities. The question is: If most of the conservation organizations are resigning their conservation goals on behalf of social issues (the sphere of the wellfunded aid organizations together with governments), in whose hands will the future of biodiversity be? Who will advocate for the defense of nature? Should the leading conservation organizations change their oxymoronic names? This trend is continually gaining traction and if conservation communities do not address this negative momentum with concrete proposals, the consequences for global conservation could be devastating. Unquestionably, conservation has entered a new age. As a consequence, it is imperative to clarify which are and which are not real conservation goals in order to invest wisely only on projects which are beneficial for conservation.

Nowadays, a "Hegelian end to history" is being pursued, resolving the dialectic with a paradigm shift on the priority of functions that a protected area must perform. The protectionist paradigm, which defends the necessity of strict conservation, is being replaced by a paradigm that is more socio-environmentalist and prioritizes the social functions of conservation under the main banner of sustainable development (Brechin et al. 2002). Alongside these lines, the idea has therefore been to put forward that strict protected areas are not viable in situations of high social pressures because people do not want them. This argument is as dangerous as stating that traffic lights are not viable at crossings where traffic is excessive and consensus is that they should be removed because people do not want to stop at a red light.

As a consequence of this predisposition, the promises of the so-called sustainable development are being carried out in areas under the category of "managed resources". In most cases, buffer or reserve areas are open to human exploitation. As a result, they cannot be differentiated (as pertains to conservation objectives) from purely productive establishments outside the parks. This is an important point: if sustainable development is useful to correct a pre-existent development inside the boundaries of protected areas mitigating the environmental damages and makes the achievement of sustainability more efficient than before, then... congratulations. But if sustainable development is masked as a new panacea to be able to dig into previously unavailable natural resources, then the ally becomes the traitor. If the socioenvironmentalists were complying with their work outside the boundaries of protected areas ever since the first protectionists began to comply with theirs in the 1890 's, a significant percentage of the Earth's surface would be now sustainable. Given that, the socioenvironmentalists would not be by now knocking on the door of the protected areas and claiming the use of resources that have survived the debacle. The debacle, of course, is the result of the fact that the natural resources preserved into the parks are surrounded by millions of cases of failed natural resources management.
The conflict between local people and conservation is intrinsically a spatial problem, say, a problem of territorial ordination of human uses: Protected areas should sustain the functions they were created for, and the supposed objectives of sustainable development should be implemented across the rest of the planet. But this is not the case: the rest of the planet is being devastated at an alarming rate and protected areas are gradually relaxing their limits. The decay of wildlife is not a necessary sacrifice for society's wellbeing; let us not kid ourselves: the devastation of natural resources advances as swiftly as hunger, inequality and poverty. After billions of dollars poured on behalf of poverty alleviation, the current world shows little progress on that matter. If the world was, is and will be full of injustice, we must then ask ourselves why effective protected areas -a tiny fraction of the Earth surface- are now linked with the cause of human misery.

\section{Conservation Crossroads and the Vagueness of the Language}

Conservation crossroads cannot be solved in part because of the vagueness of the language. As Wittgenstein (1999) puts it, the interface between words is a source of unquiet thinking, full of false meanings, oxymorons and ambiguity that cause false interactions among concepts. As in the times of "evangelization", nature is again being pushed towards the unproductive corners of the world on behalf of discourses that are camouflaged with beautiful words such as equality, welfare, democracy, humanity. They are in fact an elegant justification for the scavenging and greed of the globalized market. It is largely in "areas of freedom" that the human footprint has advanced the most. If natural areas become "freed" from the care of the State, how long they will survive is directly proportional to the time taken by the "free" markets to reach their resources (and the ethnic groups that inhabit them). With the tremendous confusion that nowadays exists, the daft idea (false link) that indigenous people are enemies of conservation has become quite trendy. On the contrary, both, cultural and natural diversity are threatened by the same enemy: it is a giant that advances at a huge step. It is so gigantic that it cannot be visible at a local scale. If it were up to this giant, there would not be a single square meter of land that would not have been seized.

A striking example of a false link between words is the oxymoronic concept of "sustainable development". Taking into account that the planet's sustainable production capacity to feed the human species was reached and exceeded ca. 1978 (Wackernagel et al. 2002) - let alone the energetic demands of other species- rather than to "sustainable development" we should be referring to a "reasonable reversal". Reversal is reasonable because it seeks to replace the impending catastrophic and irrational scenario typical of shipwrecks. It is essential to implement a program of reduction of the human footprint, both, in quantity and in intensity. This applies to us all. 


\section{Are We "the World"?}

An environmentally friendly plausible human society must be much smaller and have a completely different attitude towards nature (Næss 1989). This consists in removing humankind from the epistemological centre (as Foucault 1985 requests) in conservationist philosophy. An exclusive concern with human development often leads to undesirable impacts on biodiversity conservation (Redford et al. 2006). There are portions of ecosystems where nature must be complete in order to function, and that either do not need or actually resist human presence (Terborgh 1999; Terborgh et al. 2001). We humans need space to sustain our wellbeing (and protected areas have much to offer), but it is unviable to presume that we need the entire planet for productive activities. It has already become evident (Wackernagel et al. 2002) that if we do not limit our humongous appetite, even an entire planet will not be enough. Human economy will not be possible either if we do not allow nature to function correctly (Sachs 2008), the dialectic is resolved when understanding that the only way to adapting to a plausible future is to cede spaces in a mosaic of coexistence (Toledo 2005).

\section{The Green Leviatan}

At these crossroads that we are analyzing, we see that one of the main problems to carry out effective conservation in a mosaic of coexistence is the tension that exists between public and individual interests. Individuals prioritize their interests in the short term and in the reduced environment for the convenience of their group (Velázquez Delgado 2006). As we put it above, this - the Hardin's tragedy of the commons - is one of the great problems in conservation biology. Hobbes' assertion in the $17^{\text {th }}$ century "homo homini lupus" is hard to refute when looking back into historical evidences (Hobbes 2006). If humans destroy each other in defense of their own interests ("bellum omnium contra omnes"), it would be ingenuous to expect a majority's consensus to be concerned about other species for generations still to come or for what - roughly - might occur to the planet in future scenarios. It is very hard to get present generations to give up even a small amount of its present welfare for the sake of a better future. This behavior is "reasonable" if we base it on a demolishing argument: as the bearing of time as a variable is unidirectional, the present is in no way dependent on what might come to be in the future. In other words, what has the future done for us for us to have to do something for it? Given that the inverse relationship is opposite (in a cause-and-effect sense), the irresponsible behavior of past generations has led to "that future" and become present in our every day life (Cecchetto 2007). Ecologically sound projects at a global scale, such as the maintenance of the ecosystems working order, exceed the lifetime of the present generation (Green 1977). In addition to this, as decisions in a particular area may have ecological consequences that go beyond the sphere of that area, the responsibility cannot be delegated to the local management level. Local consensus is necessary to accomplish conservation goals, but it is not enough. It is evident that the State (in the democratic sense of res publica) must make decisions for the common good, at a global scale and in the long term, because future survival depends on this.

Nevertheless, as Ortega y Gasset states in The Revolt of the Masses, the government lives the day hidden in the present, and avoids solving current conflicts imposed upon by the urgent circumstances of the moment, neither delving into the future nor constructing anything for the long-term survival, even if its opportunities to do so are vast. In addition, there are many governments subordinated to the power of multinational corporations and, therefore, conservation goals cannot be warranted in the hands of these countries.

At this point we have another crossroads in conservation politics: How can responsibility be in the hands of the national government if this is unable to manage the resources in an efficient way? This argument - together with the recognition of the local people's rights to use their natural resources and the indigenous people's rising claims on the property of the territories they inhabit - is used to support the bottom-up against the top-down decision making. This is a wrong argument. At local level, decisions are made ad hoc, on a case-by-case basis, often under political pressure and driven by the demands of the moment. The ultimate challenge is counteracting the tragedy of the commons. Experience teaches that restraint in the use of renewable resources will not spring up from the bottom. The selfish demands of the clamorous few are promoted over the diffuse interests of a passive majority. Instead of looking downwards to find the solution, when the State is not reliable we have to look higher up: global and long-term conservation correct decisions must be in the hands of a partnership of national governments to take priority over the sovereignty of the member nations.

\section{Where do We Go from Here?}

Local versus global and people versus nature crossroads are not necessarily antagonist forces if each State -in a global partnership- is able to rank the federal territory following priorities for long-term biodiversity conservation and ecosystem services without trespassing the primordial function of protected areas as a tool for conservation. As stated in the Principle of Subsidiarity in many national laws (Esain 2009), local consensus is essential to implement conservation goals on the ground, but it should never be opposed to global priorities, especially because this opposition puts the functioning of the ecosystem at risk. Given the hierarchical structure of nature (Bailey 1987; Klijn \& Udo de Haes 1994; Monjeau et al. 1998), in which upper components (climate, geology) influence the features and functioning of the lower components (soil, vegetation), most of the ecological systems and their interactions are not 
Table 1. Proposed scheme of decision-making that matches the hierarchical structure of natural components and processes with the hierarchy of political decisions. This scheme proposes the integration of local and regional forces following a top-down cascade of enforcement.

\begin{tabular}{cccc}
\hline Scale & $\begin{array}{c}\text { Natural components and } \\
\text { processes potentially affected }\end{array}$ & $\begin{array}{c}\text { Biotic division } \\
\text { potentially affected }\end{array}$ & $\begin{array}{c}\text { Suggested hierarchical level } \\
\text { of decision making }\end{array}$ \\
\hline World & Climate & Biosphere & Global, International environmental authority \\
Continental & Geology, geomorphology & Biomes & Multinational at continental level \\
National & Geomorphology, soils, hydrology & Biomes and ecoregions & Multinational at regional or national level \\
Sub-national & Soils, hydrology & Ecoregions and habitats & State, department, province \\
Local & Hydrology, vegetation, fauna & Habitats and microhabitats & Municipality, local \\
\hline
\end{tabular}

politically divisible at a local level. Therefore, it is crucial to structure the decision making process hierarchically, from global to local, so that the State aligns to the local forces in their effort to implement conservation, without losing its organizational role (Table 1). The alliances global-local must be negotiated in a participative manner with an unequivocal priority on conservation goals.

In addition to the international conventions like the Convention on Biological Diversity (CBD), some initiatives are tested in search of allies for conservation at larger scale. For instance, in Brazil, the tax on the circulation of goods and services (ICMS) is collected by the government and is distributed among towns (municipios) mainly following the criteria established in the federal constitution ( $75 \%$ of the total) combined with the criteria of each state legislative congress (remaining 25\%) in proportion to environmental conservation units and watershed protection areas (Young \& Roncisvale 2002). This is a good example of a top-down initiative where the large-scale conservation goals are negotiated between the national and state governments and the local level. This incentive is successful in encouraging municipios to increase the total area under conservation inside their boundaries, both public and private, since this represents a higher budget. Hierarchy is the key of success in this decision making process. Firstly, the decision making process at local level should be subordinated to global goals. Secondly, it should always reinforce the levels of protection. As the ICMS example, environmental legislation and economic instruments are developing favorably in this direction in several South American countries, although many of these legislative solutions are still in cradle.

As a concluding remark, a possible way-out from these conservation crossroads might consist in being able to distinguish friends from dangerous enemies (with their affable words) for both, biodiversity conservation and local livelihoods, especially from a Latin American perspective. The ecological history of this part of the world is full of Trojan horses.

\section{Acknowledgments}

I would like to thank John Terborgh, Eduardo Rapoport, Magdalena Stanulescu, Alicia Bugallo, Fabián Gonzalez, Katrina Brandon, Fernando Fernandez, Jim Barborak, Amanda Paulos, Leonardo Cermelo and Ricardo Rozzi for their influence in the ideas expressed in this essay. Their opinions do not necessarily convey an agreement with my viewpoints. This work is an updated version of a conference given on behalf of The Conservation Land Trust. I am grateful to the Consejo Nacional de Investigaciones Científicas y Técnicas and Instituto de Análisis de Recursos Naturales for their financial support.

\section{References}

Agrawal A \& Redford KH, 2007. Conservation and displacement: and overview. In: Redford KH \& Fearn E (Ed.). Protected areas and human displacement: a conservation perspective. New York: Wildlife Conservation Society. p. 4-15. (Working Paper, 29).

Allison, GW, Lubchenco J \& Carr MH, 1998. Marine reserve are necessary but not sufficient for marine conservation. Ecological Applications, 8:579-592.

Andrade GI, 2005. Science and society at the World Park Congress. Conservation Biology, 19:4-5.

Bailey RG, 1987. Suggested hierarchy of criteria for multiscale ecosystem mapping. Landscape and Urban Planning, 14:313-319.

Belovsky GE, 1987. Extinction models and mammalian persistence. In: Soulé ME (Ed.). Viable populations for conservation. Cambridge: Cambridge University Press. p. 35-57.

Brandon K \& Wells M, 1992. Planning for People and Parks: Design Dilemmas. World Development, 20:557-570.

Brandon K, 1998. Perils to parks: the social context of threats. In: Brandon K, Redford K \& Sanderson S (Ed.). Parks in Peril: People, Politics, and Protected Areas. Washington, DC: Island Press. p. 415-440.

Brandon K, 2002. Putting the right parks in the right places. In: Terborgh J et al. (Ed.). Making Parks Work. Washington, D.C.: Island Press. p. 443-467. 
Brandon K, Redford K \& Sanderson S (Ed.). 1998. Parks in Peril: People, Politics, and Protected Areas. Washington, DC: Island Press.

Brechin S et al., 2002. Beyond the Square Wheel: Toward a More Comprehensive Understanding of Biodiversity Conservation as Social and Political Process. Society and Natural Resources, 14:41-46.

Brooks TM et al., 2006. Global biodiversity conservation priorities. Science, 313:58-61.

Brosius JP, 2007. Reflections on conservation, displacement, and exclusion. In: Redford KH \& Fearn E (Ed.). Protected areas and human displacement: a conservation perspective. New York: Wildlife Conservation Society. p. 106-112. (Working Paper, 29).

Bruner AG et al., 2001. Do Parks Protect Tropical Biodiversity? Science, 291:125-128.

Burton PJ et al., 1992. The value of managing for biodiversity. Forestry Chronicle, 68:225-237.

Cecchetto S, 2007. ¿Una ética de cara al futuro? Derechos humanos y responsabilidades de la generación presente frente a las generaciones por venir. Andamios, 3:61-80.

Delrio WM, 2005. Memorias de expropiación. Sometimiento e incorporación indígena en la Patagonia 1872-1943. Buenos Aires: Universidad Nacional de Quilmes.

Esain J, 2009. Competencias Ambientales. Buenos Aires: Abeledo Perrot.

Foucault M, 1985. Las palabras y las cosas. Buenos Aires: Planeta Agostini.

Green RM, 1977. Intergenerational distributive justice and environmental responsibility. Bioscience, 27:260-265.

Hardin G, 1972. Exploring new ethics for survival. New York: Viking Press.

Hegel GWF, 1966. Fenomenología del espíritu. México: Fondo de Cultura Económica.

Hobbes T, 2006. Leviatán. México: Fondo de Cultura Económica.

Interagency Ecosystem Management Task Force, 1995. The ecosystem approach: Healthy ecosystems and sustainable economies. Washington, DC.: White House Office of Environmental Policy.

Klijn, F \& Udo de Haes HA, 1994. A hierarchical approach to ecosystems and its implications for ecological land classification. Landscape Ecology, 9:89-104.

Kramer RA et al., 1997. The last stand: protected areas and the defence of tropical biodiversity. Oxford: Oxford University Press.

Meffe G \& Carroll R, 1997. Principles of conservation biology. Massachusetts: Sinauer \& Co.

Monjeau JA \& Solari H., 2008. Conservacionismo. In: Biagini H. \& Roig A. (Ed.). Diccionario de Pensamiento Alternativo. Buenos Aires: Editorial Biblos. p. 54-55.

Monjeau JA et al., 1998. Plants, small mammals, and the hierarchical landscape classifications in Patagonia. Landscape Ecology, 13:285-306.
Monjeau JA, 2007. Conservación de la biodiversidad, áreas protegidas y gente: escalas diferentes, problemas diferentes. In: Fundação O Boticario de Proteção à Natureza - FBPN. Unidades de Conservação: Atualidades e tendências. Curitiba: FBPN. p. 77-91.

Monjeau JA, 2009. La naturaleza abierta y sus enemigos. In: Monjeau JA (Ed.). Ecofilosofía. Curitiba: Fundação O Boticario de Proteção à Natureza. p. 235-259.

Næss A, 1989. Ecology, Community and Lifestyle: Outline of an Ecosophy. Cambridge: Cambridge University Press.

Newmark W, 1987. A land-bridge island perspective on mammalian extinctions in western North American parks. Nature, 325:430-432.

Peterson MN, Peterson MJ \& Peterson TR, 2005. Conservation and the myth of consensus. Conservation Biology, 19:762-767.

Redford KH \& Fearn E. (Ed.). 2007. Protected areas and human displacement: a conservation perspective. New York: Wildlife Conservation Society. (WCS Working Paper, 29).

Redford KH, Robinson JG \& Adams WA, 2006. Parks as shibboleths. Conservation Biology, 20:1-2.

Richter B \& Redford K, 1999. Conservation of biodiversity in a world of use. Conservation Biology, 13:1246-1256.

Sachs DJ, 2008. Economía para un planeta abarrotado. Madrid: Editorial Debate.

Salafsky N \& Wollenberg E, 2000. Linking livelihoods and conservation: a conceptual framework and scale for assessing the integration of human needs and biodiversity. World Development, 28:1421-1438.

Sanderson E et al., 2002. The human footprint and the last of the wild. Bioscience, 52:891-904.

Schwartzman S, Nepstad D \& Moreira A, 2000. Arguing tropical forest conservation: people versus parks. Conservation Biology, 14:1370-1374.

Soulé MJ \& Terborgh J, 1999. Continental conservation: scientific foundations of regional reserve networks. Washington, DC: Island Press.

Terborgh J et al., 2001. Ecological melt- down in predator-free forest fragments. Science, 294:1923-1925.

Terborgh J et al., 2002. Making Parks Work. Washington, DC: Island Press.

Terborgh J, 1999. Requiem for Nature. Washington, DC: Island Press.

Terborgh J, 2004. Reflexions of a scientist on the World Park Congress. Conservation Biology, 18:619-620.

Terborgh J, 2005. Science and society at the World Park Congress. Conservation Biology, 19:5-6.

Toledo VM, 2001. Biodiversity and indigenous people. In: Levin, S. (Ed.). Encyclopedia of biodiversity. New York: Academic Press. p. 1181-1197.

Toledo VM, 2005. Repensar la conservación: ¿áreas protegidas o estrategia bioregional? Gaceta Ecológica, 77:67-82.

Velazquez Delgado J, 2006. ¿Democracia o neoconservadurismo?. México: Editorial Torres Asociados. 
Wackernagel M et al., 2002. Tracking the ecological overshoot of human economy. PNAS, 99:9266-9271.

Wells M \& McShane TO, 2004. Integrating protected area management with local needs and aspirations. Ambio, 33:513-519.

Wilshushen P et al., 2002. Reinventing a Square Wheel: Critique of a Resurgent "Protection Paradigm" in International Biodiversity Conservation. Society and Natural Resources, 15:17-40.
Wittgenstein L, 1999. Investigaciones filosóficas. Spain: Ediciones Altaza.

Wondolleck JM \& Yaffee SL, 2000. Making collaboration work: lessons from innovation in natural resource management. Washington, DC.: Island Press.

Worldwide Fund for Nature, 2006. Species and people: linked futures. Gland: WWF International.

Young CEF \& Roncisvalle CA, 2002. Expenditures, investing and financing for sustainable development in Brazil. CEPALUNDP. (Environmental and Development Series, 58).

Received: August 2010

First Decision: September 2010

Accepted: October 2010 